Portland State University

PDXScholar

Computer Science Faculty Publications and

Presentations

Computer Science

$10-2005$

\title{
Can Infopipes Facilitate Reuse in a Traffic Application?
}

\author{
Emerson Murphy-Hill \\ Portland State University \\ Chuan-kai Lin \\ Portland State University \\ Andrew P. Black \\ Portland State University, black@cs.pdx.edu \\ Jonathan Walpole \\ Portland State University
}

Follow this and additional works at: https://pdxscholar.library.pdx.edu/compsci_fac

Part of the Databases and Information Systems Commons, and the Digital Communications and Networking Commons

Let us know how access to this document benefits you.

\section{Citation Details}

"Can Infopipes Facilitate Reuse in a Traffic Application?" Emerson Murphy-Hill, Chuan-kai Lin, Andrew Black and Jonathan Walpole, (poster), OOPSLA, San Diego, California, October 2005.

This Poster is brought to you for free and open access. It has been accepted for inclusion in Computer Science Faculty Publications and Presentations by an authorized administrator of PDXScholar. Please contact us if we can make this document more accessible: pdxscholar@pdx.edu. 


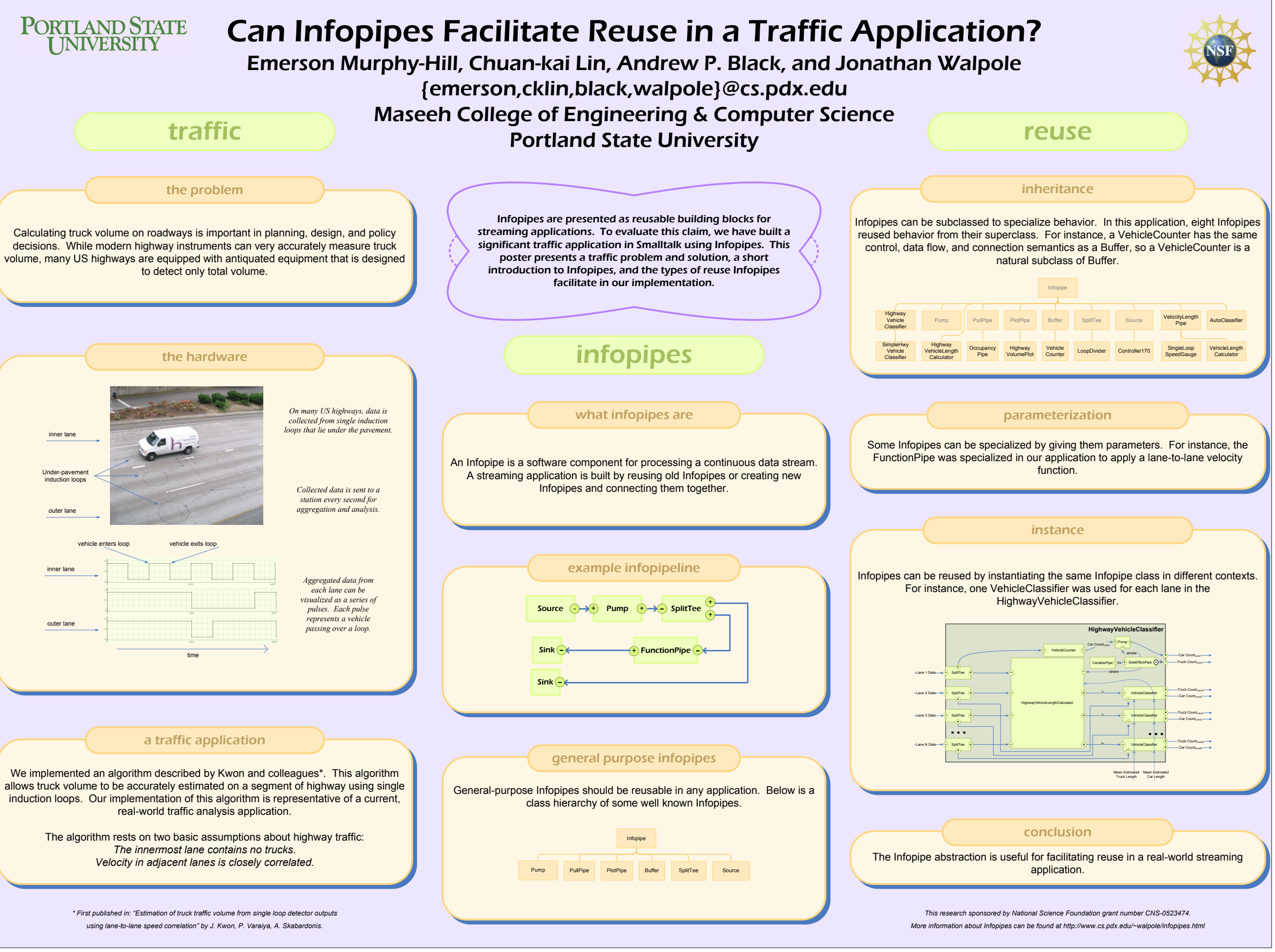

